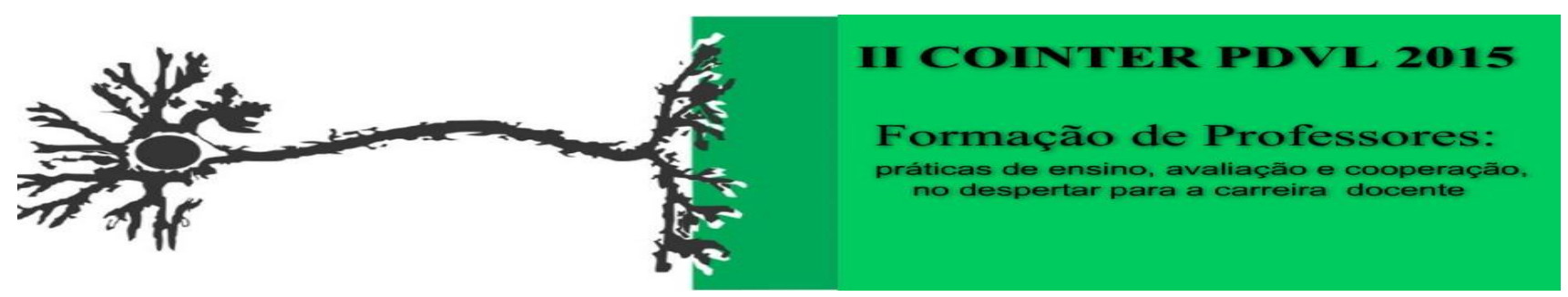

\title{
OFICINA ELETROQUÍMICA COMO PROPOSTA METODOLÓGICA PARA O ENSINO APRENDIZAGEM DE QUÍMICA
}

\author{
Apresentação: Relato de Experiência \\ Eleine Batinga Rodrigues dos Santos ${ }^{1}$; Fabrício Lúcio Lira Cansanção²; Johnnatan Duarte de \\ Freitas $^{3}$; Alan John Duarte de Freitas ${ }^{4}$
}

\section{Introdução}

A disciplina de química, atualmente, é vista como um obstáculo difícil de ser superado pela maioria dos estudantes do ensino médio. A falta de uma metodologia diversificada, o modo sistemático pelo qual essa disciplina é posta na sala de aula, contribui para a falta de interesse do aluno por não conseguir visualizar a na prática, a química teórica aprendida durante as aulas.

Segundo Amaral (1996), a própria essência da Química revela a importância de introduzir este tipo de atividade ao aluno, esta ciência se relaciona com a natureza, sendo assim os experimentos propiciam ao estudante uma compreensão mais científica das transformações que nela ocorrem.

Após levantamento realizado em diferentes escolas públicas do Estado de Alagoas, diagnosticou-se grande dificuldade dos alunos do segundo ano do ensino médio em eletroquímica, com isso foi proporcionado uma oficina intitulada por: PILHAS ELETROQUÍMICAS: RE (CRIANDO) E APRENDENDO. Esta ocorreu durante um Curso de Férias proposto por uma parceria entre os programas Novos Talentos e PDVL.

\section{Relato de Experiência}

A oficina foi desenvolvida como alternativa metodológica que pudesse favorecer a compreensão dos alunos em relação ao conteúdo. Abordando a química de modo experimental, utilizando elementos comuns do cotidiano desses jovens e tornando o processo de ensino aprendizagem mais interativo e dinâmico. A atividade foi realizada na sala de aula, onde os estudantes construíram a célula eletroquímica utilizando materiais simples e bastante conhecidos no

\footnotetext{
${ }^{1}$ Pós graduanda lato sensu em Química Tecnológica, IFAL, eleinerodrigues@hotmail.com

${ }^{2}$ Professor da Rede Estadual de Educação de Alagoas, SEE, flclira@yahoo.com.br

${ }^{3}$ Prof. Dr. em Química e Biotecnologia, IFAL, johnnatandf@gmail.com

${ }^{4}$ Prof. Dr. em Química e Biotecnologia, IFAL, ajdfifal@gmail.com
} 
seu cotidiano, como frutas e legumes. Para verificar a funcionalidade do dispositivo eletroquímico (pilha), os estudantes ficaram encarregados de realizar testes a fim de observar se a pilha, (re) criada por eles, gerou potencial elétrico suficiente para acender leds (Diodo Emissor de Luz) e ligar calculadoras além de medir com o auxílio do voltímetro, o potencial gerado pela pilha.

De modo geral foi notória a empolgação/animação dos estudantes pela proposta apresentada pelas equipes dos programas envolvidos quanto à (re) criar uma pilha eletroquímica. As ações realizadas por meio dos programas contribuíram de forma significativa para o processo de ensino aprendizagem dos alunos. De acordo com Giordan (1999), a experimentação prioriza o contato dos alunos com os fenômenos químicos, possibilitando ao aluno a criação dos modelos que tenham sentidos para ele, a partir de suas próprias observações.

Imagem 1: Realização da oficina de pilhas. Fonte: Própria

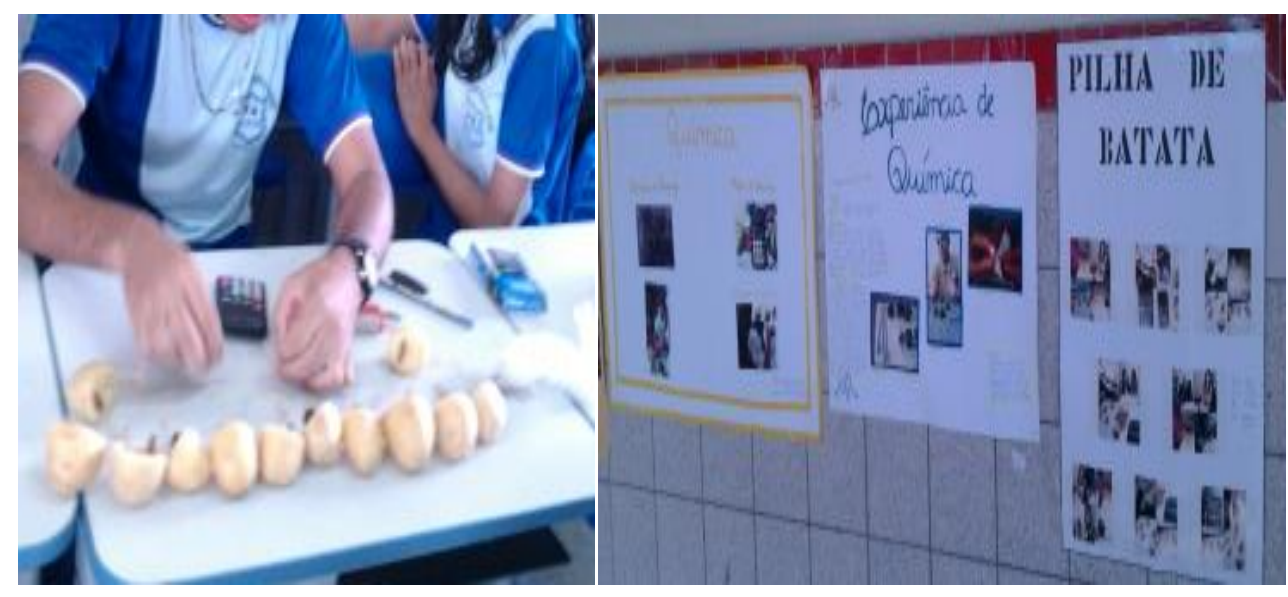

\section{Considerações}

Com essa atividade, conseguimos que os alunos mergulhassem no universo da Química, expandindo seus conhecimentos criando um elo maior entre alunos, professores e ciência, em prol da qualidade no processo ensino aprendizagem, obtendo-se dessa forma resultados satisfatórios após a realização da referida oficina.

\section{Referências}

AMARAL, L. Trabalhos práticos de química. São Paulo, 1996.

GIORDAN, M. O papel da experimentação no ensino de ciências. Química Nova na Escola, n. 10, p. $43-49,1999$. 